Bond University

Research Repository

\title{
Small-scale private equity: Demand versus supply
}

Dwyer, Bruce; Duncan, Keith; Southam, Colette

Published in:

Accounting Research Journal

DOI:

10.1108/ARJ-05-2019-0096

Licence:

Other

Link to output in Bond University research repository.

Recommended citation(APA):

Dwyer, B., Duncan, K., \& Southam, C. (2020). Small-scale private equity: Demand versus supply. Accounting Research Journal, 33(2), 363-380. https://doi.org/10.1108/ARJ-05-2019-0096

\section{General rights}

Copyright and moral rights for the publications made accessible in the public portal are retained by the authors and/or other copyright owners and it is a condition of accessing publications that users recognise and abide by the legal requirements associated with these rights.

For more information, or if you believe that this document breaches copyright, please contact the Bond University research repository coordinator. 


\section{Small Business Economics \\ Small-scale private equity: demand versus supply \\ --Manuscript Draft--}

Manuscript Number:

Full Title:

Small-scale private equity: demand versus supply

Article Type:

Original Research

Keywords:

small-scale private equity; SME; capital structure; small business finance gap;

information and market efficiency; HGF

Corresponding Author:

Colette Southam, Ph.D.

Bond University

Gold Coast, QLD AUSTRALIA

Corresponding Author Secondary

Information:

Corresponding Author's Institution:

Bond University

Corresponding Author's Secondary

Institution:

First Author:

Bruce Dwyer, PhD

First Author Secondary Information:

Order of Authors:

Bruce Dwyer, PhD

Keith Duncan, PhD

Colette Southam, Ph.D.

Order of Authors Secondary Information:

Funding Information:

Abstract:

Capital structure theories suggest corporate managers seeking external funding generally prefer debt to equity because of the tax benefits, reduced agency costs, and lack of the negative signal associated with issuing stock. Contrary to this expectation, we found that almost half the respondents from Australian small and medium-sized enterprises (SMEs) expressed an interest in seeking equity funding. Less than $5 \%$ of the SMEs seeking equity funding expressed difficulty obtaining a bank loan. The dominant preference for equity funding was based on the equity funder providing business experience to assist in growing the company, but about one third were motivated by the prospect of ongoing funding to fund its growth trajectory. Our exploration of small-scale private equity (SSPE) reveals a mismatch between supply and demand for SSPE with very few SMEs able to meet private equity (PE) firms' stringent investment criteria. We find evidence of all components of the 'small business finance gap' (Holmes and Kent 1991; Kumar and Rao 2015): unavailability of funds ('supply gap'), limited awareness of appropriate sources of funds ('knowledge gap'), accessibility of those limited financial sources ('demand gap'), and reluctance of financial sources to lend money to SMEs ('benevolence gap'). To attract investment from PE firms, SMEs must overcome the severe information asymmetry, demonstrate their quality, and reduce the cost of due diligence for SSPE firms, possibly by emulating large publicly traded firms which are subject to external audit and incorporate more sophisticated internal reporting and financial controls. 


\title{
Small-scale private equity: demand versus supply
}

\section{B. Dwyer}

Bond Business School, Bond University, Gold Coast, Australia 4229

\section{K. Duncan}

Bond Business School, Bond University, Gold Coast, Australia 4229

\section{Southam (corresponding author)}

Bond Business School, Bond University, Gold Coast, Australia 4229

e-mail: csoutham@bond.edu.au

phone: +61755952220

\begin{abstract}
Capital structure theories suggest corporate managers seeking external funding generally prefer debt to equity because of tax benefits, reduced agency costs, and the lack of the negative signal associated with issuing stock. Contrary to this expectation, we found that almost half the respondents from Australian small and medium-sized enterprises (SMEs) expressed an interest in seeking equity funding. Less than five percent of the SMEs seeking equity funding expressed difficulty obtaining a bank loan. The dominant preference for equity funding was based on the equity funder providing business experience to assist in growing the company, but about one third were motivated by the prospect of future capital to fund its growth trajectory. Our exploration of smallscale private equity (SSPE) reveals a mismatch between supply and demand for SSPE with very few SMEs able to meet PE firms' stringent investment criteria. We find evidence of all components of the 'small business finance gap' (Holmes and Kent 1991; Kumar and Rao 2015): unavailability of funds ('supply gap'), limited awareness of appropriate sources of funds ('knowledge gap'), accessibility of those limited financial sources ('demand gap'), and reluctance of financial sources to lend money to SMEs ('benevolence gap'). To attract investment from PE firms, SMEs must overcome the severe information asymmetry, demonstrate their quality, and reduce the cost of due diligence for SSPE firms, possibly by emulating large publicly traded firms which are subject to external audit and incorporate more sophisticated internal reporting and financial controls.
\end{abstract}

Keywords Small-scale private equity - SME - Capital structure - Small business finance gap Information and market efficiency - HGF

JEL Classifications $\quad$ G32 - G23 - G14 


\title{
Small-scale private equity: demand versus supply
}

\begin{abstract}
Capital structure theories suggest corporate managers seeking external funding generally prefer debt to equity because of the tax benefits, reduced agency costs, and lack of the negative signal associated with issuing stock. Contrary to this expectation, we found that almost half the respondents from Australian small and medium-sized enterprises (SMEs) expressed an interest in seeking equity funding. Less than 5\% of the SMEs seeking equity funding expressed difficulty obtaining a bank loan. The dominant preference for equity funding was based on the equity funder providing business experience to assist in growing the company, but about one third were motivated by the prospect of ongoing funding to fund its growth trajectory. Our exploration of smallscale private equity (SSPE) reveals a mismatch between supply and demand for SSPE with very few SMEs able to meet private equity (PE) firms' stringent investment criteria. We find evidence of all components of the 'small business finance gap' (Holmes and Kent 1991; Kumar and Rao 2015): unavailability of funds ('supply gap'), limited awareness of appropriate sources of funds ('knowledge gap'), accessibility of those limited financial sources ('demand gap'), and reluctance of financial sources to lend money to SMEs ('benevolence gap'). To attract investment from PE firms, SMEs must overcome the severe information asymmetry, demonstrate their quality, and reduce the cost of due diligence for SSPE firms, possibly by emulating large publicly traded firms which are subject to external audit and incorporate more sophisticated internal reporting and financial controls.
\end{abstract}

\section{Introduction}

This study juxtaposes the theory on supply and demand for small-firm capital raisings by lifting the veil of opaqueness from the small-scale private equity (SSPE) markets themselves. Simeonov (2015) identifies 'the size and fragmentation of capital markets' as a major obstacle to equity capital raising for small and mediumsized enterprises (SMEs). Contemporary research on the impact of information asymmetry on small-firm capital raisings is inadequate (Abosede and Oseni 2011). However, the inability to raise capital ultimately affects the performance of SMEs (Kumar and Rao 2015) which are economically important; in Australia, privately-held SMEs contribute 57\% of the country's GDP (National Australian Bank 2017) and employ 4.7 million people (Gilifillan 2015). Furthermore, small-listed firms constitute $86 \%$ of the listings on the Australian Securities Exchange (ASX 2017). Given the market importance of SMEs, this study aims to kindle an academic discourse to improve our understanding of, and ultimately liquidity, in small-scale capital markets.

This study focuses on two SSPE capital market actors: the demand side SMEs, including high-growth firms (HGFs) seeking capital to maintain their growth trajectory; and the supply side, the financial intermediaries with a focus on the smaller, nimbler private equity (PE) firms. On the demand-side, we survey Australian SMEs on their capital-raising preferences. Widespread evidence of SME's restricted access to funding is welldocumented in the economic and financial literature (Harjoto and Paglio 2011; Klonowski 2012; Paulet et al. 2014; Kumar and Rao 2015). Holmes and Kent (1991) report the 'small business finance gap' has two components: the unavailability of funds ('supply gap'), and SME limited awareness of appropriate sources of funds ('knowledge gap'). Kumar and Rao (2015) enhance this list with two additional components: the 
accessibility of limited financial sources ('demand gap'), and the reluctance of financial sources to lend money to

SMEs ('benevolence gap').

On the supply side, we examine whether and when smaller PE firms are predisposed to take equity positions in SMEs. Much of the investment supply-side literature concerns large PE firms seeking to take over listed companies or debates on active versus passive management of large, indexed equity portfolios (Chen et al. 2010). The literature tends to focus on PE firms targeting larger, undervalued, poorly governed, or underperforming listed companies (Lonergan 2007; Clarkson et al. 2016), for which there is substantial available audited data (Osborne et al. 2012; Rath and Rashid 2016). To the best of our knowledge, our Australian study is ground-breaking in that it gathers substantial private industry data to determine the financial equilibrium, if any, between small incorporated PE providers and SMEs, including HGFs.

The paper consists of six sections: Section 2 surveys the literature and develops hypotheses; Section 3 describes the research design; Section 4 presents results from both the supply and demand sides; Section 5 discusses the results and their implications; Section 6 concludes the study.

\section{Theoretical background and research hypotheses}

Information asymmetry in equity markets may result in adverse selection, since the owners and managers have more relevant knowledge about their projects than the investors from whom they seek financing. Without sufficient information transfer, the equity markets will not reflect project quality as demonstrated in Akerlof's (1970) hypothetical used-car market ${ }^{1}$. The negative impact of information asymmetry on large, publicly-listed corporation asset pricing has been studied extensively (Leland and Pyle 1977; Reinganum and Smith 1983; Myers and Majluf 1984; Clarke et al. 1999; Baker and Wurgler 2007), but its effects on small firms remain underresearched. Information asymmetry is likely to be more severe for small firms because of their 'close nature i.e., being controlled by one person or a few related people and their having fewer disclosure requirements' (Hall, Hutchinson and Michaelas 2000). It is widely accepted that the increased perception of risk in poorly-informed capital markets drives prices downwards (Grossman and Stiglitz 1976) because potential investors progressively discount equity prices as the amount of information asymmetry increases (Myers and Majluf 1984). This study explores the demand and supply in the SSPE market where we expect a more severe level of asymmetric information than its larger-capitalized counterparts.

\subsection{Demand side}

On the demand side, Modigliani and Miller (M\&M; 1958) laid the basic foundation for the development of capital structure theories: trade-off theory; pecking order theory; agency cost theory; and market timing theory. Following from M\&M, static trade-off theory (Kraus and Litzenberger 1973) implies firms move toward a target debt/equity ratio that balances tax benefits with the costs of financial distress. Pecking order theory (Myers and Majluf 1984; Myers 1984) suggests a preference hierarchy, starting with internal financing, then relatively inexpensive debt,

\footnotetext{
${ }^{1}$ Akerlof describes a used car market with low-quality 'lemons' and high-quality 'cherries' and information asymmetry where the buyer does not know whether a given car's type is a lemon or a cherry. This can lead to adverse selection where sellers with better private information about the quality of a product will selectively participate in trades which benefit them the most which will leave only 'lemons' behind and result in the eventual failure of the market.
} 
and lastly, equity with the higher cost of its associated information asymmetry. Agency theory (Jensen and Meckling 1976) predicts that an optimum debt/equity ratio exists where agency costs (between owners/managers and shareholders, and between debt and equity holders) are minimized. Lastly, market timing theory (Baker and Wurgler 2007) suggests a firm's current capital structure is a result of all past attempts to time the market.

Myers (1984) addresses the 'capital structure puzzle'; his regressions do not support the existence of target debt/equity ratios. He reports debt levels much lower than predicted by trade-off theory, and provides support for both pecking order theory and market timing theory. Berger, Ofek, and Yermack (1997) use agency theory to explain why there is a leverage level lower than the 'optimal' one predicted by trade-off theory. Jensen (1987) extends agency theory to explain the negative implications of free cash flow ('the overinvestment problem') and the benefits of debt in disciplining managers, but also provides support for pecking order theory as managers demonstrate a preference to fund projects internally to avoid the scrutiny which accompanies raising external capital. The literature focuses on the differences among capital structure theories, but Fama and French's (1992) observation that firms with debt capacity are most likely to issue debt (unless they have stock price runups), demonstrates these theories 'do not need to be mutually exclusive' (Fama and French 1992; Cotei and Farhat 2009). In our view, a general preference for debt reflects the pecking order hierarchy, tax advantage of debt (tradeoff theory), elimination of the 'overinvestment problem' (agency theory) and avoids the negative signal of issuing equity (market timing theory).

In applying capital structure theories to small firms, one would generally predict SME owners seeking external funding would prefer debt over more expensive equity. However, Forsaith and McMahon (2002) and Brettel et al. (2009) report SMEs have a more positive attitude to external equity emanating from a 'perceived' increase in the value of the firm which outweighs the negatives, including loss of control. Mac An Bhaird and Lucey (2010) find Irish SMEs that have insufficient assets to obtain debt funding are less averse to diluting their shareholding to obtain equity, although their primary preference may be for debt funding in accordance with pecking order theory. This highlights the need to reconcile the firm's theoretical 'preference' with the actuality of a firm's financial structure. An SME owner may hold a certain idealized external funding preference (Holmes and Kent 1991), but in practice must accept the reality of the accessibility of limited financial sources (Kumar and Rao 2015).

Policymakers seeking to encourage growth, innovation, and productivity look to SMEs, and in particular HGFs, as SMEs represent a significant proportion of the private economy worldwide (Lewis and Zalan 2012). A small firm on a high-growth trajectory inevitably exhausts available sources of property-collateralized debt funding and owner's unsecured personal loans. In Australia, many HGFs are unable to meet Australian banks' requirements to qualify for significant senior debt (Deloitte 2013); for example, the study found lack of acceptable collateral was responsible for up to $37 \%$ of loan rejections. The small number of HGFs that qualify for significant bank debt, without offering real property security, are likely to have onerous covenants applied to their loans. Ramlee and Berma (2013) suggest banks could be 'more realistic' when devising covenants on loans to nascent HGFs, speaking to the existence of the 'benevolence gap,' which Kumar and Rao (2015) termed for the reluctance of financial sources to lend money to SMEs.

\subsection{Supply side}


PE is capital that is not listed on a public exchange and is provided by both institutional investors and retail Zalan 2012; Bertoni et al. 2013), while PE firms typically invest at a later stage (Bertoni et al. 2013). A contemporary manifestation of private equity investment is the business angels concept, wherein wealthy individuals make small non-intermediated equity investments into closely held start-up companies (Sørheim 2005). However, business angel funding should not be confused with PE, as the informal structure and scale of an angel investment differs significantly from the formal structure and scale of a PE investment (Lewis and Zalan 2012).

Large PE firms (listed or unlisted) employ highly-leveraged strategies to buy underperforming and/or underpriced listed companies (Lonergan 2007). While the literature tends to focus on these larger PE funds, Willert's (2008) comprehensive study of North American-managed PE funds revealed that over 52\% of PE firms are small, employing only two to seventeen investment professionals. The current study focuses on small-scale Australian counterparts to examine the 'small business finance gap' described by Holmes and Kent (1991). Lewis (2012) refers to this overlooked segment of PE as 'private PE,' which is difficult to quantify because it lacks visibility. Wealthy Australian family dynasties incorporated as Family Offices are thought to be equity investors in SMEs, but their investments also remain 'secretive and under the radar' (Smith 2014). The PE industry itself is noted for its opacity when it comes to delivering performance metrics and reliable data to the public (Lewis and Zalan 2012). This contributes to the 'knowledge gap,' the limited awareness of appropriate sources of funds mentioned by Holmes and Kent (1991).

The 'small business financing gap' (Holmes and Kent 1991) sits between start-up and later-stage funding. Figure 1 illustrates that as firms grow, they move from owners' capital and venture capital to traditional PE, Debt and ultimately public capital markets to fund their growth. There exists a role for SSPE in bridging this gap. Few previous studies have attempted to suggest applied solutions rather than simply explore this gap (Lewis and Zalan 2012). However, two decades ago, Berger and Udell (1998) believed they were then witnessing the emergence of the supply of intermediated SSPE to SMEs. Our paper shows that this emergence has not reached any significant scale, and investigates the underlying reasons.

\section{Insert figure 1 here}

Forsaith and McMahon (2002) noted that the financing decisions for SMEs may be different from those of larger companies. We hypothesize that this is related to the four components of the 'small business finance gap' (Holmes and Kent 1991; Kumar and Rao 2015). Specifically, we test the following hypotheses:

H1: Australian SMEs' preference for SSPE is greater than one would expect based on traditional capital structure theories owing to the lack of accessibility of the existing limited financial sources or owing to the reluctance of financial sources to lend money to SMEs.

\section{H1a: There exists a 'demand gap.' \\ H1b: There exists a 'benevolence gap.'}

H2: The sources of Australian SSPE are inadequate, or Australian SMEs have a limited awareness of appropriate sources of equity funding. 
H2a: There exists a 'supply gap' for SMEs seeking equity funding.

$\mathrm{H} 2 \mathrm{~b}$ : There exists a 'knowledge gap' among SMEs seeking equity funding.

\section{Research design}

We employ a survey to gather data from the demand side of the market, which consists of many small to medium entities that are geographically dispersed. The study questions are included in a larger annual industry survey with which respondents are familiar. However, the supply-side market participants are limited in number and potentially more private concerning their business dealings. Therefore, an interview and archival approach were adopted to gather data from the supply side. Our mixed-methods approach reflects the nature of the demand and supply-side markets (Eisenhardt and Graebner 2007).

\subsection{Demand-side research design}

A questionnaire design is employed to gather data on SMEs' growth and demand for funding. The demand-side survey was integrated into the NSW Business Chamber's annual survey electronically administered to its 26,000 members, representing virtually all industries and ranging in size from self-employed up to two-hundred employees. A total of 1,092 completed questionnaires (4\% of the members) are included in this study. Combining with the Chamber's survey improved the legitimacy and response rate for our research.

From the demographic data elicited by the NSW Business Chamber's questions, combined with specific questions about growth and funding preferences, we identify potential high-growth SMEs from the pool of generic SME respondents. HGFs are defined by the Organization for Economic Cooperation and Development (OECD) as firms with ten or more employees that generate employment growth of $20 \%$ or more for three consecutive years (Publishing 2010). Extant literature is in broad agreement that only about 6-8\% of any given SME population meet this definition of an HGF, but concludes they create the majority of new jobs (AnyadikeDanes et al. 2009; Henrekson and Johansson 2010; Lopez-Garcia and Puente 2012; Mason and Brown 2013; Lee 2014). However, Daunfeldt et al. (2014) claim that using employment growth to measure HGFs could be seriously misleading, as firms measured in 'terms of employment are not the same firms as HGFs measured regarding productivity and their economic contributions differ significantly.' To identify potential HGFs, this study uses a mixture of growth in revenue, profits, CAPEX, and employment as indicators of growth. We also identify firms that are seeking equity or potentially seeking equity from the broader set of responding SMEs.

\subsection{Supply-side research design}

The supply-side participants in the small-scale private equity market are identified from the 55 PE firms registered with the Australian Private Equity and Venture Capital Association Limited (AVCAL). ${ }^{2}$ From this list, we

\footnotetext{
${ }^{2}$ As of 21 February 2017.
} 
identified 15 small-scale PE firms. Triangulating AVCAL data with the registered firms' website information

\section{Results}

This section reports the results. Firstly for the demand-side survey of SMEs, and secondly for the semi-structured interviews of the supply-side PE firms. We then discuss the results and the implications for industry and policy makers.

\subsection{Demand-side results}

\subsubsection{Growing SMEs}

The survey resulted in 1092 usable responses from SMEs regarding growth expectations and demand for funding. The SMEs indicated whether they expected their growth in the next three months to be lower, about the same, or higher. Table 1, panel A reports that a third of the respondents expect revenue to grow, slightly less expect profit to grow and about $12 \%$ expect staff to grow. This evidence suggests measuring growth solely in terms of only employment might underestimate the proportion of growth firms as many more firms expect financial growth but not staff growth. In total, 78 firms, or $7 \%$ of respondents, expect all three aspects of the business, revenue, profit, and staff, to grow. Using all three factors combined is a more encompassing approach to identify potential HGF investments. 
Respondents also reflected on their last quarter CAPEX spending and hiring of new staff. Panel B of

Table 1 shows the most common CAPEX was for asset replacement, but about $10 \%$ of respondents had either invested in improving the product capacity or lowering operating costs. Such CAPEX expenditure is another potential indicator of firms that are growing. Similarly, we asked respondents about their last quarter hiring. While $25 \%$ had hired to replace staff, others had hired to obtain new skills and $15 \%$ had hired to increase capacity or to be able to meet expected demand. Hiring for expansion or new skills potentially is another indicator of growing firms. Replacing existing staff might also be a weak indicator in that staff turnover may partly reflect growth pressures in the business.

Insert table 1 here

\subsubsection{SMEs seeking equity}

There is a surprisingly high proportion of SMEs that are seeking or might seek equity funding. In total, 505 firms, or $46 \%$ of the respondents, are either seeking equity (227 firms or 20.8\%) or might seek equity (278 firms or $25.5 \%$ ), providing strong support for $\mathrm{H} 1$. This represents a large potential demand for equity investment and suggests this sector could be fruitful for PE firms to target.

To profile the firms that currently seek equity, Table 2 reports the relative size of these SMEs in terms of employee numbers and revenue. More than $20 \%$ of firms seeking equity have more than twenty employees. If we split the ' 5 to 20 ' range, it suggests approximately $40 \%$ of the firms have 10 or more employees, consistent with the base for the OECD high growth definition. In addition, more than $40 \%$ of the firms seeking equity generate more than $\$ 1$ million in revenue.

\section{Insert table 2 here}

Table 3 shows the breakdown in the levels of equity offered by SMEs seeking equity funding. The 227 firms seeking equity are about evenly split between those offering equity of $30 \%$ of less and those offering equity of $40 \%$ or more. The percentage of equity being offered is relatively large given entrepreneurial SMEs are renowned for wanting to limit ownership dilution. Nevertheless, most firms are still looking to retain control with only about $20 \%$ prepared to give up $50 \%$ or more of equity.

\section{Insert Table 3 here}

Figure 2 demonstrates that respondents' reasons for seeking an equity partner provide additional insights into why SMEs express a higher interest in equity financing than would be expected by capital structure theory (H1). These results suggest firms have both debt capacity and access to debt, but still expressed an interest in equity financing. Of the $227 \mathrm{SME}$ respondents prepared to embrace equity funding, only 14 firms or $4.4 \%$ expressed difficulty obtaining a bank loan. Rather, a dominant motivation of respondents (53.24\% of SME respondents) for seeking equity funding was to tap the business knowledge of an experienced investor/partner to assist in growing the company. Equity-seeking SMEs (32.9\%) were also motivated by the prospect of ongoing funding as the firm continued its growth trajectory.

\section{Insert figure 2 here}

\subsubsection{Identifying high-growth SMEs seeking equity}

One key question is, how many of the growing SMEs that are seeking equity could be considered high growth and thus potentially be of interest to PE firms? Investors including PE firms are looking for returns, and those with faster returns, given the time value of money, are more valuable. To determine how many of our 227 equityseeking SMEs show growth signs that may indicate they are more suitable to PE firms, we combined the growth, 
CAPEX, and staff hiring indicators of potential growth. We can then filter potential investee SME firms based on

individual measures or combinations of the measures.

Initially, we employ a wide definition of growth. Panel A of Table 4 reports the number of firms that could be classified as higher growth, based on any one of the three growth indicators: expected growth in revenue, profits, or staff. About $10 \%$ of the respondents expect growth in any one of these factors and are seeking equity funding. This number doubles (20.9\%) if we include the (untabulated) number of firms that are not sure and might seek equity. Another approach is to combine 'seeking equity' with any one of the growth indicators and other factors. Specifically, we can add whether in the last quarter the firm engaged in either CAPEX or staff hiring. Combining any growth indicator and one of these past quarter indicators increases the subsample of potential growth firms to 74 or about $7 \%$ of the sample (again, this doubles if we include the potential equity seekers). This is similar to the $6 \%$ HGF segment identified in offshore studies of entire SME populations using employment growth as a criterion (Anyadike-Danes et al. 2009; Henrekson and Johansson 2010; Lopez-Garcia and Puente 2012; Mason and Brown 2013; Lee 2014; Coad et al. 2014).

\section{Insert table 4 here}

If PE firms want to further tighten the screen for high-growth firms, then the potential investments to evaluate would reduce. To simulate this, we define high-growth investee firms as those seeking equity that exhibit all three expected growth indicators (revenue, profit, and staff), and one of the past growth indicators (either CAPEX or staff hiring last quarter). We refer to this as our narrow definition of growth. When we apply this narrower definition to the data we find 18 or $1.6 \%$ of the sample exhibit all three growth indicators (panel B of Table 4). Of these, 14 or $1.3 \%$ of the sample qualify under the tighter screen of last quarter indicators and expected future growth.

While this seems a small proportion, it is a potentially large market when we consider the number of SMEs in Australia. The Australian Bureau of Statistics (ABS) documents there are over 2.1 million SMEs operating in Australia. Table 5 shows that if $1.3 \%$ of these SMEs are high-growth SMEs, then this implies approximately 28,000 potential high-growth SMEs are seeking equity from SSPE firms in Australia. This is a sizeable market demand for SSPE.

\section{Insert table 5 here}

However, this analysis may underestimate the level of high-growth SMEs suitable for PE firms as the literature extrapolated population proportion, using a single measurement criterion (Moreno and Casillas 2007; Navarro et al. 2012; Lee 2014) rather than the multiple criteria this study employs, suggests as many as 120,000 HGFs exist in Australia. In the next section, we consider the supply side to this potentially large market for SSPE and contrast these estimates with the experience of SSPE suppliers.

\subsection{Supply-side results}

The 15 small-scale private equity firms targeted for an interview proved reclusive consistent with Lewis and Zalan's (2012) findings. Potential respondents cited fear of breach of confidentiality as grounds to withhold interview consent, despite formal written assurances of anonymity. Thirteen of the 15 targeted AVCAL member respondents eventually agreed to grant interviews. The other two respondents were recruited from AVCAL member recommended family-PE firms. A series of structured questions was put to each of the respondents in the 
course of a 30-minute telephone interview. Table 6 profiles the respondent PE firms and shows that 7 of the 15 PE firms interviewed operated for ten years or longer and the oldest for some seventy years.

Insert table 6 here

\subsubsection{Structure of Australian private equity firms}

The structure of PE firms in Australia is different to elsewhere in the world. The Limited Partnership structures that characterize United States (US) and European PE firms are not recognized by The Australian Securities and Investments Commission (ASIC), Australian Prudential Regulation Authority (APRA), or the Australian Tax Office (ATO). The only approved Australian Limited Partnerships are related to Venture Capital. These are structured as state-registered Early Stage Venture Capital Partnerships (ESVCLPs) and Venture Capital Partnerships (VCLPs) and attract significant tax concessions. A respondent, whose minimum investment was $\$ 10$ million, commented, 'I think some of my competitor's VCLPs have more to do with Private Equity than VC. They are stretching it. The trouble is ASIC-approved Unit Trusts come with a lot of expensive and complex regulatory baggage. We spend more time on governance paperwork than growing our assets.' Another respondent emphasized the ASIC cap on the size of Australian VCLPs: 'ASIC permits VC style Limited Partnerships to be extended to PE providing the total investment assets of the partnership do not exceed $\$ 250$ million. If the total investment assets exceed $\$ 250$ million, then the investments must be in the form of a Unit Trust.' The same respondent opined that 'further investment into start-ups and SMEs is being held back as a direct result of the current inconsistency in the tax rules that apply to the different classes of investors in VCLPs and their extension into limited partnership small-scale Private Equity.'

Midway through the interviews, the 2016/17 Australian Government budget was released, flagging some form of limited PE partnership (a Collective Investment Vehicle or CIV) to be introduced for the income years starting on or after 1 July 2018 (Australian Government 2016). This proposal is aimed at reducing the onerous ASIC compliance load associated with Investment Trusts.

Table 6 reports that 13 of the 15 respondents relied on variants of ASIC-approved Unit Trust structures to channel institutional and wholesale funds into their PE investments. Figure 3 illustrates the typical PE investment fund structure. The dominant typology is a branded unit trust-based fund. In this structure, each fund owned and managed multiple Special Investment Vehicles (SPVs), with each SPV housing an individual portfolio company. Individual fund risk was mitigated by the diversity of investment and the quarantined SPVs. Only one respondent assigned a separate Unit Trust for each investment portfolio company.

Insert figure 3 here

Without exception, all respondents' Unit Trusts were licensed by ASIC as wholesale trusts, thus avoiding the need to meet the far more complex ASIC and APRA regulations that govern retail trusts. A high-profile respondent with a legal background stated, 'The compliance requirements of registered retail funds are very complex and expensive to implement. Consequently, retail investors are not part of our fund sourcing model.' Unlike retail trusts, managers of wholesale PE Funds/Unit trusts cannot discuss or accept investments from 'mom $\&$ pop' non-sophisticated investors. Nor can they advertise or use financial planners to promote their funds.

Given the current prohibition in Australia of the simpler internationally recognized limited partnership model, the Australian PE respondents were still able to devise strategies to debt leverage their assets to their 
advantage. The most utilized domestic strategy involved assigning the debt to the SPV portfolio companies (the portfolio company to take out a bank loan, and it's made easier if the parent PE company has high-level connections with the bank.'

\subsubsection{Raising investment funds}

ASIC prohibits wholesale licensed PE funds from raising capital directly from the public. Table 6 shows that most PE firms raise investment funds from either sophisticated investors termed high-net-worth individuals (HNWI) or institutional superannuation funds (INT). ASIC defines HNWI as individuals able to produce an accountant's certificate proving they own minimum net assets of $\$ 2.5$ million and receive a minimum gross income of $\$ 250,000$ p.a. Research suggests that over half of institutional PE capital is sourced from large Australian superannuation funds (O'Hare 2016). A respondent summed up the current sourcing practices of nine of the study's 15 respondents: 'Our sources are 100\% institutional superannuation funds. HNWI and self-managed super funds (SMSF) are too small for us.'

The interview process identified that the five smallest PE respondents did not have the connections, track record, or access to the large, compelling deals (\$50 million plus) needed to attract institutional capital. One of these five respondents complained the restrictive nature of their wholesale fund license 'made it illegal to engage with licensed financial planners and hence made access to capital from large superannuation funds more difficult.' Instead, apart from their own 'skin in the game,' the five smallest PE firms relied almost entirely on a network of HNWI. Three of these smaller respondents had been sourcing from the same HNWI for more than a decade. Funding emanating from HNWI is more likely to be measured in individual contributions of one million or less. Nonetheless, one of these five smaller respondents summed up a consensus opinion on SSPE: 'That there is no shortage of sophisticated investor funds for a compelling well-researched proposal.'

One PE firm adopted a different capital raising strategy. They used the weight of their ASX listing to issue a secondary equity offering to raise capital for acquisitions in a narrowly-defined industry sector. This respondent observed, 'We intend to operate as direct owners of the portfolio assets, as our objective is to be a single industry-based company. This strategy avoids us being seen as an investment company pure and simple and avoids the complexity and onerous requirements of Unit Trusts.'

\subsubsection{Taxonomy of SSPE investments}

The PE firm respondents stated that compelling middle and lower-market HGF investment opportunities were scarce in Australia, thus justifying the generalist approach adopted by $12(80 \%)$ of them. One firm with a narrower focus invested in SMEs as distressed assets. The 12 generalist respondents agreed industry specialization would generate a higher return on their investments but claimed, 'Here in Australia we can't get the comparative advantage of specialization because there aren't enough opportunities.' The three that did take equity positions in a narrower range of industries, targeted industries that required sophisticated skills, included medical technology, nursing homes, IT services, and financial services. The median number of investments was only five and ranged from none to 12 (see Table 6). 
No respondent currently held a sub \$1 million equity investment (see Table 6), nor did they appear positions in the sub $\$ 1$ million HGFs, including:

1. The absolute cost of due diligence was the same regardless of the size of the target making it more efficient to apply this cost to a larger target because it becomes smaller in percentage terms. A respondent with prior experience in the US commented, 'the problem with small investments is that small dollars yield small dollar returns and small dollar fees but still requires a lot of time and frictional costs. In New York City (NYC) at my $\$ 4$ billion funds I had a team of 5 at my disposal and the ability to incur significant deal costs - even if the deal failed. Here in Australia doing small investments I can't afford significant expenses or the risk of dead deal costs, so I have to pick my deals carefully and do the work myself to contain costs.' The sole respondent who had experimented with sub $\$ 1$ million investments advised: 'We folded the trust three years ago ... the cost of carrying out due diligence on small private companies far outweighs any significant capital gains, both in per centage and absolute terms.'

2. The information asymmetry that typifies small firms is often exacerbated by the owner's manipulation of profits by opaque journal entries, basic accounting systems running unlocked without an audit trail, out of date records, and general lack of internal controls. A respondent stated, 'Auditing small firms and their primitive accounting systems is risky and costly.'

3. Growth by 'buy and build strategies' can be difficult to implement. A larger respondent observed, 'Buy and build is a furphy with really small acquisitions. Small firms can't be cheaply and easily consolidated under a single brand due to huge variations in cultures, management styles, and systems.'

All respondents screened targets against a checklist of 'must-have' characteristics before commencing in-depth due diligence. Table 7 summarizes the t10 key investment criteria common to all 12 generalist respondents. An essential component of the screen is the long-term growth prospects of the investee and includes factors related to size, earnings, cashflows, management, leverage capacity, equity pricing, and control. The 12 generalist respondents emphasized that they applied the same standard selection criteria to all equity investments, be they large or small. The respondent that specialized in acquiring and restructuring/rebuilding distressed companies sourced them from administrators or receivers. They were acquired at a low expense/value ratio and met an investment criterion that required the target's net tangible asset backing to exceed the acquisition price.

\section{Insert table 7 here}

A reoccurring issue in deal identification was the high value that owners of rapidly growing, but relatively unprofitable and cash-strapped, firms put on their equity. A respondent commented, 'When they (the target's owners) learn that we are from private equity, they start mouthing stratospheric EBITDA multiples. They value their operations at up to ten times EBITDA.' Six respondents claimed exploiting smaller HGF's latent growth potential was often hampered by lack of profits in absolute terms. A small HGF's EBITDA might not be sufficient to fund an effective replacement team if the incumbent management team lacked the vision and competence needed to take the company to the next level. The respondent for the largest PE firm interviewed for this study stated, 'We see SMEs as a much higher due diligence risk due to their relatively uneducated managers. Economies of scale mean that their EBITDA will not support a package to attract the calibre of manager we require.' Several respondents saw \$300-400,000 remuneration packages as essential to attract and retain visionary strategic 
managers. The need to initially subsidize high-calibre management salaries meant larger acquisitions, with earnings sufficient to cover the remuneration of exemplary executive talent, were more attractive.

\subsubsection{Percentage equity sought}

Only two of the respondents sought $100 \%$ equity. Sixty percent (nine respondents) were prepared to accept a minimum 50/50 joint venture, although they preferred a majority shareholding. However, the two youngest PE firms were prepared to fund as low as $20 \%$ equity, providing the acquisition agreement allowed them to exercise ultimate control through a structure of voting and non-voting shares. The respondent who managed the largest number of unit trusts stated, 'We deliberately seek a minority position provided we have the formal ability to influence key strategic decisions and exercise some operational control.'

\subsubsection{How investments are sourced}

SSPE firms stressed they had to proactively search for investment grade opportunities. All cited lack of investment grade opportunities as the major retardant to the growth of SSPE. A typical respondent summed it up: 'We only do three deals a year - we find some ourselves - others come to us - but let me tell you it (sic - finding investment grade investments) is like finding a needle in a haystack.' Several of the respondents were aware of the literature's claim (Moreno and Casillas 2007; Navarro et al. 2012; Lee 2014) of the existence of tens of thousands of HGFs in Australia. They questioned the validity of the data, as the theoretical abundance of HGFs was not supported by their field experience. For example, one respondent had found only a single complying investment in the previous 12 months, in spite of employing an extensive and innovative search methodology.

Another respondent that had attempted to target HGFs commented, 'Sure, on paper there are supposed to be ten thousand or more high-growth SMEs out there, and that was the big attraction to us. However, tracking down high-growth SMEs that meet our investment criteria proved extremely difficult. Members of our network may recommend firms, but few of their recommendations survive our preliminary due diligence. For example, most of them have management that lacks the ability to carry them to the next level. That means if we proceed, we become a recruiting firm.' Irrespective of the quantity issue, respondents identified six main sources they had used to identify potential high-growth firms they could investigate as potential deals. Table 8 summarizes the sources. Most of the approaches are informal and involve some element of networking. There is not a common or formal process for identifying potential high-growth SME investees.

Insert table 8 here

\subsection{Explaining the absence of SSPE from SME funding}

Three tiers of information asymmetry inhibit the SSPE industry. Firstly, potential providers are invisible to HGFs. Secondly, HGFs, even those with a compelling investment case, are invisible to PE firms. Thirdly, the financial opaqueness of small firms makes them unattractive to professional equity investors. The dominant operational explanation for the absence of SSPE from SME funding paradigms is a lack of supply, which provides support for H2a, the existence of a 'supply gap.' While we find the PE firms are unanimous that SSPE funding is available for 'compelling' investments able to pass the industries' screening criteria, the taxonomy of the descriptor 'compelling' appeared to be more qualitative than quantitative. This provides support for both H1a, that there 
exists a 'demand gap' due to the lack of accessibility of the existing limited financial sources which is tied to the reluctance of PE sources to lend money to SMEs (H1b, the existence of the 'benevolence gap').

PE firms perceive there is a scarcity of compelling SME investments while demand for PE is high among SMEs, which suggests most Australian SMEs currently fail to demonstrate their attractiveness to PE firms. It is not surprising that we find evidence of an existing 'knowledge gap' (evidence for H2b) among SMEs about the providers of equity funding, given that the relevant PE firms are camouflaged by 'the size and fragmentation of capital markets' (Simeonov 2015). However, by becoming knowledgeable about the requirements of the providers of equity funding, SMEs could devise strategies to better signal their quality to potential equity investors. The literature is mute on this issue, but the most obvious answer would be for SMEs to emulate larger firms and employ professional capital raising intermediaries familiar with capital markets and incur the associated agency (brokerage) costs. This is consistent with the certification arguments provided by Booth and Smith (1986). Mainstream PE funds are biased toward large-scale positions, partly because the agency and out-of-pocket costs per transaction are low when calculated as a percentage of the total investment (Engel and Stiebale 2014). Large targets generally have a history of external auditing, which effectively reduces the cost of financial due diligence.

The costly ASIC licensed intermediary structure is also a deterrent to SSPE growth. As of 31 July, 2018, public consultant is underway on the proposed Australian Government bill to form a limited partnership (a Collective Investment Vehicle or CIV), which would be required to meet similar audit criteria to the current managed investment trusts but will be easier to set up and administer. They can be leveraged with debt. Investors in the new CIVs will generally be taxed as if they had invested directly. It is possible the introduction of CIVs will facilitate SSPE, but not enough is yet known to make this statement with any certainty.

\section{Discussion}

SSPE is a multifaceted capital funding model, which in practice is impaired by information asymmetry as the actors are all but invisible to each other. PE firms target 'compelling' acquisitions managed by a visionary team, preferably with 'skin in the game,' who possess outstanding organizational core competencies that enable them to act unilaterally. Given high-performance management already in place, the PE firms limit their operational involvement in portfolio companies to generalized top-down strategic advice. Only larger, proven HGFs have the potential to meet PE firms' stringent investment criteria. From a PE firm's perspective, an HGF acquisition's growth would depend on its in situ proven visionary management team, or a recruited high-performance management team as a last resort. The latter strategy necessitates the targeted investment generate sufficient EBITDA to cover the salaries of the recruited high-performance executives.

We find the PE respondents are unanimous that SSPE funding is always available for 'compelling' investments able to pass the industries' screening criteria. The taxonomy of the descriptor 'compelling' is profitbased, but the descriptor 'visionary management' is as much qualitative as quantitative. The organizational core competencies that underpin the perception of 'visionary management' require further research before they can be employed as a useful screening criterion.

Equity agency and frictional costs contribute to the scarcity of SSPE. The PE firm respondents applied the same intensive due diligence procedures to all acquisitions regardless of size. Therefore, as contended by Briozzo and Vigier (2009), SSPE transactional costs are high for the sub-\$1 million funding segment. Mainstream 
PE funds are biased toward large-scale positions, partly because agency and out-of-pocket costs per transaction have a history of external auditing, which further reduces the cost of financial due diligence. SSPE would be more attractive to investors if SMEs were regularly audited; with cloud-based accounting systems and lower audit costs through offshoring, this is becoming more feasible.

We find the demand by SMEs for equity funding is far greater than capital structure theories would lead us to expect, especially as the demand emanated from SMEs that qualified for bank funding. Capital structure theories suggest corporate managers seeking external funding would generally prefer debt to equity because of the associated tax benefits, reduced agency costs and lack of the negative signal that accompanies equity issuance, but $46 \%$ of our respondent SMEs expressed an interest in seeking equity funding. We found the greater-thanexpected HGFs' demand for equity capital was predicated on both the utility of strategic management guidance from the PE investor and the prospect of ongoing funding. Note the current study did not explore the market timing explanation nor the dilution effects of ongoing equity funding or a capital structure involving PE firm backed senior debt.

The capital structure literature is less applicable to SMEs where survival often takes precedence over value maximization. Most capital structure studies relate theory to factors such as firm size, asset structure, profitability, agency costs, information asymmetry, life cycle, and historical growth, rather than attitudinal imperatives. Norton (1991) found small-growth firms have 'a strong aversion to debt,' which is consistent with Briozzo and Vigier's (2009) conclusion that behavioural variables, such as an emotive involvement with personal debt, influences SMEs' preferred capital structure. Limited research, such as Forsaith and McMahon (2002), examines the predisposition to external equity, especially qualitative influences such as an owner's visionary expectation of high growth. The owner's growth vision links demand with supply, as this study finds that a visionary management team (allied with organizational competence) is precisely what PE firms prefer.

However, the reality of supply is that small unlisted companies, even the successful ones, do not have access to sophisticated financial instruments such as convertible notes, debentures, and low cost junk bonds. According to Forsaith and McMahon (2002) and confirmed by this study, SME's have limited access to any form of external equity. PE firm respondents held that larger acquisitions exhibited less information asymmetry because they were subject to external audit and they had more sophisticated internal reporting and financial controls than smaller firms. We join Forsaith and McMahon (2002) in calling for qualitative research on the behavioural attitudes that would enable SMEs to overcome this information asymmetry. Brettel et al. (2009) support our contention, noting the sparsity of studies on behavioural motivations likely to influence an SME's owner's predisposition to equity finance.

The literature suggests most SMEs seed capital comes from savings, family or friends, or maybe a small business loan in the guise of a home mortgage. Beyond the seed capital stage, we suggest underresearched factors come into play. We contend that successful SME owners quickly recognize their own weaknesses, or their enterprise would have stalled shortly after take-off. Success in this context is not necessarily spectacular growth. This may attract investors, but it is not an exclusive measure of success. Stability and consistent profitability count. If SME owners need to employ management expertise for their firm's continued success, they may feel more secure if the 'expert' has some skin in the game, in the manner that large companies incentivize and retain 
key employees with share options. This last behavioural trait may explain why the SMEs in our study that qualified for bank loans preferred equity partners instead.

Apart from the handful of supply-side respondents in this study, a readily identifiable source of SSPE for companies beyond the seed capital stage does not appear to exist in Australia. Given the unmet demand suggested by this study, examining potential sources of SSPE may be a fertile field for future research. For example, Family Offices $^{3}$ could play an increasing role in filling this void. We contend much of the past theoretical research has been focused on demand for SSPE rather than supply.

The multiple criteria we employed to identify unlisted HGFs contrasts with the widely-used single criterion, such as employment or revenue growth, that characterize most of the literature definitions of HGFs. Contrary to the studies of Lee (2014), Navarro et al. (2012), and Moreno and Casillas (2007), which perceive HGFs to be up to $10.6 \%$ of a given SME population, our three qualitative measures suggest HGFs may constitute only about $1 \%$ of a given SME population. However, such a miniscule population supports our PE respondent's claims finding an investment calibre HGF is analogous to the 'needle in a haystack' analogy.

To overcome the high levels of information asymmetry, small firms must find ways to signal their quality to identifiable cohorts of professional equity investors, thus improving access to capital which will yield improvements in productivity and employment opportunities. The development of models that would assist with screening and selection criteria for assessing the soundness of the financial performance projections of potential investments would greatly assist potential small-firm investors. We encourage policymakers to legislate for stringent disclosure obligations to mitigate the information asymmetry that inhibits the creation of new innovative sources of small-firm equity capital funding and the launch of a formal SSPE industry.

\section{Conclusions}

Contrary to expectations based on capital structure theories, we found $46 \%$ of Australian SMEs expressed an interest in seeking equity funding despite a stated ability to acquire additional debt. SME's demand for equity funding was predicated on both the utility of strategic management guidance from the PE investor and the prospect of ongoing funding to assist in growing the company. Our study reveals a mismatch between supply ('supply gap') and demand for SSPE with very few SMEs able to meet PE firms' stringent investment criteria, providing evidence of the lack of accessibility of the existing limited financial sources ('demand gap') and the reluctance of financial sources to lend money to SMEs ('benevolence gap'). In order to attract investment from PE firms, SMEs need to remedy their limited awareness of appropriate sources of funds ('knowledge gap') in order to overcome the extreme levels of information asymmetry in the small capital markets. SMEs can emulate larger publicly traded acquisitions which are subject to statutory external audit and incorporate more sophisticated internal reporting and financial controls than their smaller competitors.

\footnotetext{
3 Australia's Family Office is a network for private banks dedicated to managing the assets for high wealth families. A specialized part of the business, the family office provides anything from staff and travel management services to supervision of trusts and investment and might become the vehicle for the globalizaization of Australian family businesses, serving as the place for increased networking for family business owners around the world.
} 


\section{References}

Abosede, A. J., \& Oseni, J. E. (2011). Theoretical analysis of firm and market-specific proxies of information asymmetry on equity prices in stock markets. Australian Journal of Business and Management Research, 1(2), 1-13.

Akerlof, G. A. (1970). The market for "lemons": Quality uncertainty and the market mechanism. The Quarterly Journal of Economics, 84(3), 488-500.

Anyadike-Danes, M., Bonner, K., Hart, M., \& Mason, C. (2009). Measuring business growth: High growth firms and their contribution to employment in the UK. National Endowment for Science, Technology and the Arts (NESTA).

ASX (2017). ASX Listing Rules 3.1 and 3.1A. ASX 2017 (pp. 1-15). Australia: ASX Listing Rules Guidance Note 8.

Australian Government (2016). Budget Paper No. 2, Budget Measures 2016-17. Budget. Canberra, Commonwealth of Australia.

Baker, M., \& Wurgler, J. (2007). Investor sentiment in the stock market. Journal of Economic Perspectives, 21(2), 129-151.

Berger, A. N., \& Udell, G. F. (1998). The economics of small business finance: The roles of private equity and debt markets in the financial growth cycle. Journal of Banking \& Finance, 22(6-8), 613-673.

Berger, P. G., Ofek, E., \& L. Yermack, D. L. (1997). Managerial entrenchment and capital structure decisions. The Journal of Finance, 52(4), 1411-1438.

Bertoni, F., Ferrer, M. A., \& Martí, J. (2013). The different roles played by venture capital and private equity investors on the investment activity of their portfolio firms. Small Business Economics, 40(3), 607-633.

Booth, J. R., \& Smith, R. L. (1986). Capital raising, underwriting and the certification hypothesis. Journal of Financial Economics, 15(1-2), 261-281.

Brettel, M., Breur, W., Espel, P., \& Abedin, A. (2009). Private equity for SME: A behavioral model of the demand-side perspective. SSRN Electronic Journal, 1-44.

Briozzo, A., \& Vigier, H. (2009). A demand-side approach to SMES'capital structure: Evidence from Argentina. Journal of Business and Entrepreneurship, 21(1), 30.

Chen, C., Comerton-Forde, C., Gallagher, D. R., \& Walter, T. S. (2010). Investment manager skill in small-cap equities. Australian Journal of Management, 35(1), 23-49.

Clarke, J., Dunbar, C., \& Kable, K. M. (1999). Long-run performance and insider trading in completed and cancelled seasoned equity offerings. Journal of Quantitative Analysis, 36(4), 415-430.

Clarkson, P. M., Pathan, S., \& Tellam, A. (2016). Do private equity target firms exhibit less effectual governance structures? Australian Journal of Management, 41(2), 244.

Coad, A., Daunfeldt, S., Johansson, D., \& Wennberg, K. (2014). Whom do high-growth firms hire? Industrial and Corporate Change, 23(1), 293-327.

Cotei, C., \& Farhat, J. (2009). The trade-off theory and the pecking order theory: Are they mutually exclusive? North American Journal of Finance and Banking Research, 3(3), 1-16.

Daunfeldt, S., Elert, N., \& Johansson, D. (2014). The economic contribution of high-growth firms: Do policy implications depend on the choice of growth indicator? Journal of Industry, Competition and Trade, 14(3), 337-365.

Deloitte (2013). Access to capital for small and medium-sized enterprises. In N. B. Chamber (Ed.), Small business access to finance (pp. 23-58). Sydney.

Dick, B. (2000). Grounded Theory: A thumbnail sketch.

Eisenhardt, K. M., \& Graebner, M. E. (2007). Theory building from cases: Opportunities and challenges. Academy of Management Journal, 50(1), 25-32.

Engel, D., \& Stiebale, J. (2014). Private equity, investment and financial constraints: Firm-level evidence for France and the United Kingdom. Small Business Economics, 43(1), 197-212.

Fama, E. F., \& French, K. R. (1992). The cross-section of expected stock returns. The Journal of Finance, 47(2), 427-465.

Forsaith, D. M., \& McMahon, R. (2002). Equity financing patterns amongst Australian manufacturing SMEs: Flinders University of South Australia, School of Commerce.

Gilifillan, G. (2015). Statistical snapshot: Small business employment contribution and workplace arrangements. In G. o. A. P. R. Publications (Ed.). Canberra, Australia.

Grossman, S. J., \& Stiglitz, J. E. (1976). Information and competitive price systems. The American Economic Review, 66(2), 246-253.

Harjoto, M. A., \& Paglio, J. K. (2011). Funding continuum for private business owners: Evidence from Pepperdine Private Capital Markets Project Survey. Journal of Entrepreurial Finance, 15(2), 1-22.

Henrekson, M., \& Johansson, D. (2010). Gazelles as job creators: A survey and interpretation of the evidence. Small Business Economics, 35(2), 227-244. 
Holmes, S., \& Kent, P. (1991). An empirical analysis of the financial structure of small and large Australian manufacturing enterprises. Journal of Small Business Finance, 1, 141-154.

Jensen, M. C. (1987). Agency Cost of Free Cash Flow, Corporate Finance and Takeovers. American Economic Review, 76(2), 650-659.

Jensen, M. C., \& Meckling, W. H. (1976). Theory of the firm: Managerial behavior, agency costs and ownership structure. Journal of Financial Economics, 3(4), 305-360.

Klonowski, D. (2012). Liquidity gaps in financing the SME sector in an emerging market: Evidence from Poland. International Journal of Emerging Markets, 7(3), 335-355.

Kraus, A., \& Litzenberger, R. H. (1973). A state-preference model of optimal financial leverage The Journal of Finance, 28(4), 911-922.

Kumar, S., \& Rao, P. (2015). A conceptual framework for identifying financing preferences of SMEs. Small Enterprise Research, 22(1), 99-112.

Lee, N. (2014). What holds back high-growth firms? Evidence from UK SMEs. Small Business Economics, 43(1), 183-195.

Leland, H. E., \& Pyle, D. H. (1977). Informational asymetries, financial structure, and financial intermediation. The Journal of Finance, 32(2), 371-387.

Lewis, G., \& Zalan, T. (2012). The unexplored dimension of private equity: The case of prudential equity partners. The Journal of Private Equity, 40-54.

Lonergan, W. (2007). Private equity: The emperor's new clothes? The Finsia Journal of Applied Finance(2), 28.

Lopez-Garcia, P., \& Puente, S. (2012). What makes a high-growth firm? A dynamic probit analysis using Spanish firm-level data. Small Business Economics, 39(4), 1029-1041.

Mac An Bhaird, C., \& Lucey, B. (2010). Determinants of capital structure in Irish SMEs. Small Business Economics, 35(3), 357-375.

Mason, C., \& Brown, R. (2013). Creating good public policy to support high-growth firms. Small Business Economics, 40(2), 211-225.

Modigliani, F., \& Miller, M. H. (1958). The cost of capital, corporation finance and the theory of investment. The American Economic Review, 48(3), 261-297.

Moreno, A. N., \& Casillas, J. C. (2007). High-growth SMEs versus non-high-growth SMEs: A discriminant analysis. Entrepreneurship and Regional Development, 19(1), 69.

Myers, S. C. (1984). The capital structure puzzle. Journal of Finance, 39, 575-592.

Myers, S. C., \& Majluf, N. S. (1984). Corporate financing and investment decisions when firms have information that investors do not have. Journal of Financial Economics, 13, 187-221.

National Australian Bank (2017). Part 1: Moments that matter: Undestanding Australian SMEs. Business Research and Insights: Business View, Melbourne.

Navarro, J. L. B., Casillas, J. C., \& Barringer, B. (2012). Forms of growth: How SMEs combine forms of growth to achieve high growth. Journal of Management and Organization, 18(1), 81-97.

Norton, E. (1991). Capital structure and small firm growth. Journal of Small Business Finance, 1(2), 161-177.

O’Hare, M. (2016). Preqin Insight: Alternative Assets in Australia. New York: Preqin Inc.

Osborne, S., Katselas, D., \& Chapple, L. (2012). The preferences of private equity investors in selecting target acquisitions: An international investigation. Australian Journal of Management, 37(3), 361.

Paulet, E., Parnaudeau, M., \& Abdessemed, T. (2014). The SME struggle for financing: A clampdown in European banks post-crisis. Journal of Business Strategy, 35, 36-45.

Publishing, O. (2010). OECD studies on SMEs and entrepreneurship high-growth enterprises: What governments can do to make a difference (OECD studies on SMEs and entrepreneurship). Paris: Organization for Economic Co-operation and Development.

Ramlee, S., \& Berma, M. (2013). Financing gap in Malaysian small-medium enterprises: A supply-side perspective. South African Journal of Economic and Management Sciences, 16(5), 115-126.

Rath, S., \& Rashid, M. (2016). Undervaluation and private equity takeovers. Australian Journal of Management, 41(4), 735-759.

Reinganum, M. R., \& Smith, J. K. (1983). Investor preference for large firms: New evidence on economies of size. The Journal of Industrial Economics, 32(2), 213-227.

Simeonov, K. (2015). EU capial markets initiatives for better financing SMEs. Online Journal Modelling the New Europe, Sept(16), 43-67.

Behind the dynasty millions: Family offices. (2014, 29 January 2014). Australian Financial Review.

Sørheim, R. (2005). Business angels as facilitators for further finance: An exploratory study. Journal of Small Business and Enterprise Development, 12(2), 178-191.

Strauss, A., \& Corbin, J. (1998). Basics of qualitative research. Newbury Park, C.A.: Sage.

Willert, F., \& zu Knyphausen-Aufsess, D. (2008). What determines the size of private equity firms? Schmalenbach Business Review, 60(1), 32-49. 
Table 1 Expected growth of SMEs

\begin{tabular}{|c|c|c|}
\hline & Number & Percentage \\
\hline SME Survey Respondents & 1092 & $100 \%$ \\
\hline \multicolumn{3}{|l|}{ Panel A: Expected Growth } \\
\hline \multicolumn{3}{|l|}{ Expecting Growth in: } \\
\hline Revenue & 356 & $33 \%$ \\
\hline Profits & 299 & $27 \%$ \\
\hline Staff & 135 & $12 \%$ \\
\hline Expecting Growth in ALL Three & 78 & $7 \%$ \\
\hline \multicolumn{3}{|l|}{ Panel B: CAPEX Spending } \\
\hline \multicolumn{3}{|l|}{ Recent CAPEX to: } \\
\hline Replace assets & 218 & $20 \%$ \\
\hline Improve product & 109 & $10 \%$ \\
\hline Increase capacity & 113 & $10 \%$ \\
\hline Lower operating costs & 78 & $7 \%$ \\
\hline Other reason & 34 & $3 \%$ \\
\hline \multicolumn{3}{|l|}{ Panel C: Growing Staff } \\
\hline \multicolumn{3}{|l|}{ Recent Hired Staff to: } \\
\hline Replace staff that left & 275 & $25 \%$ \\
\hline Obtain new skills & 88 & $8 \%$ \\
\hline Increase capacity/meet demand & 166 & $15 \%$ \\
\hline Other & 16 & $1 \%$ \\
\hline
\end{tabular}


Table 2 Size of SMEs seeking equity

\begin{tabular}{|c|c|c|}
\hline & Number & Percentage \\
\hline \multicolumn{3}{|l|}{ Employee Size of Firms Seeking Equity } \\
\hline Non-employing / Sole Operator & 27 & $12 \%$ \\
\hline 1 to 4 & 62 & $27 \%$ \\
\hline 5 to 20 & 92 & $41 \%$ \\
\hline 21 to 50 & 23 & $10 \%$ \\
\hline 51 to 100 & 10 & $4 \%$ \\
\hline 101 to 200 & 2 & $1 \%$ \\
\hline \multirow[t]{2}{*}{ More than 200} & 11 & $5 \%$ \\
\hline & 227 & \\
\hline \multicolumn{3}{|l|}{ Revenue Size of Firms Seeking Equity } \\
\hline$\$ 0$ to $\$ 250,000$ & 60 & $26 \%$ \\
\hline$\$ 250,001$ to $\$ 500,000$ & 29 & $13 \%$ \\
\hline$\$ 500,001$ to $\$ 1$ million & 38 & $17 \%$ \\
\hline$\$ 1.0$ million to $\$ 2.0$ million & 25 & $11 \%$ \\
\hline$\$ 2.0$ million to $\$ 5.0$ million & 34 & $15 \%$ \\
\hline$\$ 5.0$ million to $\$ 10.0$ million & 11 & $5 \%$ \\
\hline$\$ 10.0$ million to $\$ 20.0$ million & 17 & $7 \%$ \\
\hline \multirow[t]{2}{*}{ More than $\$ 20.0$ million } & 13 & $6 \%$ \\
\hline & 227 & \\
\hline
\end{tabular}


Table 3 Amount of equity sought by SMEs seeking equity

\begin{tabular}{lccc}
\hline & & Number & Percentage \\
\hline Amount of Equity Sought: & $10 \%$ & 13 & $6 \%$ \\
$20 \%$ & 44 & $19 \%$ \\
$30 \%$ & 58 & $26 \%$ \\
$40 \%$ & 29 & $13 \%$ \\
$49 \%$ & 34 & $15 \%$ \\
$50 \%$ & 32 & $14 \%$ \\
& & $7 \%$ \\
\hline
\end{tabular}


Table 4 Identifying growth SMEs seeking equity

\begin{tabular}{lcc}
\hline Panel A: Wide Definition of Growth & Number & Percentage \\
\hline Growth in ANY One (Revenue, Profit or Staff) & 108 & $9.9 \%$ \\
PLUS: Last Quarter CAPEX or Hired Staff & 74 & $6.8 \%$ \\
& & \\
\hline Panel B: Narrow Definition of Growth & 18 & $1.6 \%$ \\
\hline Growth in ALL Three (Revenue and Profit and Staff) & 14 & $1.3 \%$ \\
PLUS: Last Quarter CAPEX or Hired Staff & & \\
\hline
\end{tabular}


Table 5 Potential high-growth SMEs in Australia

\begin{tabular}{lr}
\hline & Number \\
\hline Small firms in Australia (employees 0-19) & $2,119,200$ \\
Medium firms in Australia (employees 20-199) & 52,200 \\
Total SMEs & $2,171,400$ \\
\hline & \\
\hline
\end{tabular}

Source: ABS Counts of Australian Businesses June 2017

(http://www.abs.gov.au/AUSSTATS/abs@.nsf/Lookup/8165.0Main+Features1Jun\%202013\%20to\%20Jun\%202017?OpenDocument) 
Table 6 Investment profiles of PE firms interviewed

\begin{tabular}{|c|c|c|c|c|c|c|c|c|}
\hline $\begin{array}{l}\text { Firm } \\
\text { Code }\end{array}$ & $\begin{array}{l}\text { Firm Age } \\
\text { (Yrs.) }\end{array}$ & $\begin{array}{l}\text { Corporate } \\
\text { Structure }\end{array}$ & $\begin{array}{l}\text { Number of } \\
\text { Employees }\end{array}$ & $\begin{array}{c}\text { FUM } \\
\text { \$million }\end{array}$ & $\begin{array}{l}\text { Source of } \\
\text { Funds }\end{array}$ & $\begin{array}{l}\text { Number of } \\
\text { Investments }\end{array}$ & $\begin{array}{c}\text { Mean } \\
\text { Investment } \\
\text { \$million }\end{array}$ & $\begin{array}{c}\text { Min } \\
\text { Investment } \\
\text { \$million }\end{array}$ \\
\hline 1 & 12 & WUN & 10 & 300 & INT & 6 & 10 to 100 & 10 \\
\hline 2 & 9 & WUN & 17 & 230 & INT & 9 & 25 to 50 & 20 \\
\hline 3 & 13 & LP \& WUN & 17 & $\mathrm{n} / \mathrm{a}$ & HNWI & 2 & $\mathrm{n} / \mathrm{a}$ & 10 \\
\hline 4 & 14 & LP \& WUN & 6 & 83 & INT \& HNWI & 5 & $\mathrm{n} / \mathrm{a}$ & 2 \\
\hline 5 & 5 & LP \& WUN & 15 & 1,700 & HNWI & $\mathrm{n} / \mathrm{a}$ & 2 to 25 & 1 \\
\hline 6 & 77 & MT & $\mathrm{n} / \mathrm{a}$ & $\mathrm{n} / \mathrm{a}$ & INT & $\mathrm{n} / \mathrm{a}$ & $\mathrm{n} / \mathrm{a}$ & $\mathrm{n} / \mathrm{a}$ \\
\hline 7 & 39 & WUN & 46 & 1,975 & INT & $\mathrm{n} / \mathrm{a}$ & $\mathrm{n} / \mathrm{a}$ & $\geq 10$ \\
\hline 8 & 1 & WUN & 3 & $\mathrm{n} / \mathrm{a}$ & HNWI & 1 & 1 to 45 & $\leq 1$ \\
\hline 9 & 18 & WUN & 15 & 650 & INT \& HNWI & 11 & 1 to 5 & 1 \\
\hline 10 & 17 & WUN & 4 & $\mathrm{n} / \mathrm{a}$ & SMSF & 3 & 1 to 4 & $\leq 1$ \\
\hline 11 & 16 & WUN & 9 & $\mathrm{n} / \mathrm{a}$ & INT & 5 & $100-500$ & 50 \\
\hline 12 & 1 & LE & 7 & $\mathrm{n} / \mathrm{a}$ & INT \& HNWI & 7 & 1 to 4 & 1 \\
\hline 13 & 8 & WUN & 2 & $\mathrm{n} / \mathrm{a}$ & HNWI & 1 & 3 to 10 & 3 \\
\hline 14 & 3 & WUN & 2 & $\mathrm{n} / \mathrm{a}$ & HNWI & 1 & 2 to 20 & 2 \\
\hline 15 & 1 & WUN & 3 & $\mathrm{n} / \mathrm{a}$ & HNWI & 12 & 4 to 40 & 0.5 \\
\hline
\end{tabular}

Structure codes: WUN = Wholesale Unit Trust; MT = Master Trust; LP = Limited Partnership; LE = Listed Entity.

Fund codes: INT = Institutional Superannuation Fund; HNWI = High-Net-Worth Individual; SMSF = Self-Managed Super Fund. 
Fig. 1 Potential role of SSPE in SME funding

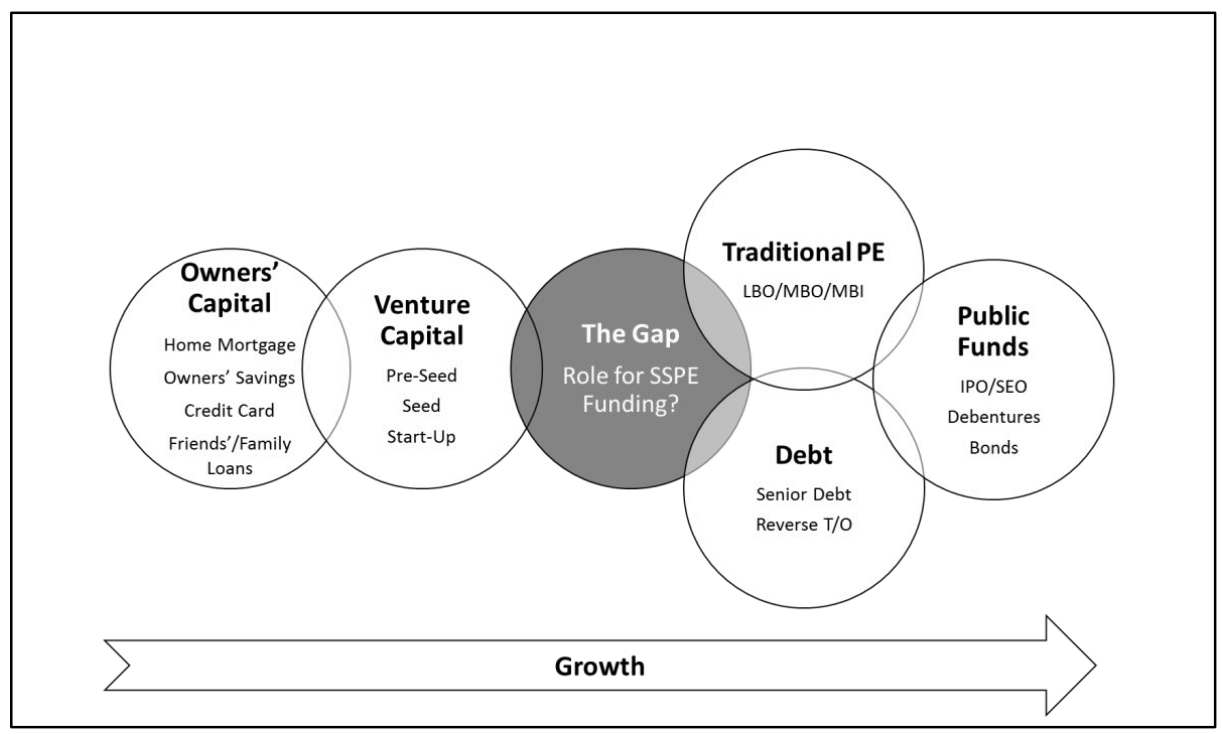


Fig. 2 Reasons SMEs seeking equity funding

An experienced investor/partner could bring valuable new skills to assist the...

The right equity partner could continue to fund the business as it grows

It doesn't matter where the funding comes from, my business is a winner

My business has difficulty obtaining a bank loan

We are confident that the business will eventually be listed on the stock exchange

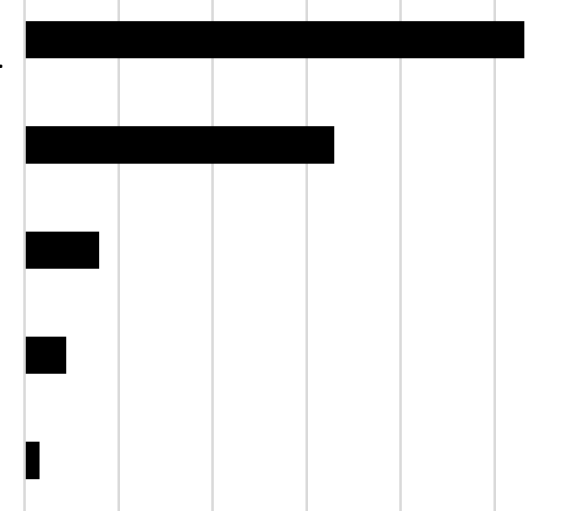

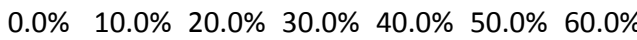


Fig. 3 Model of a typical PE investment fund

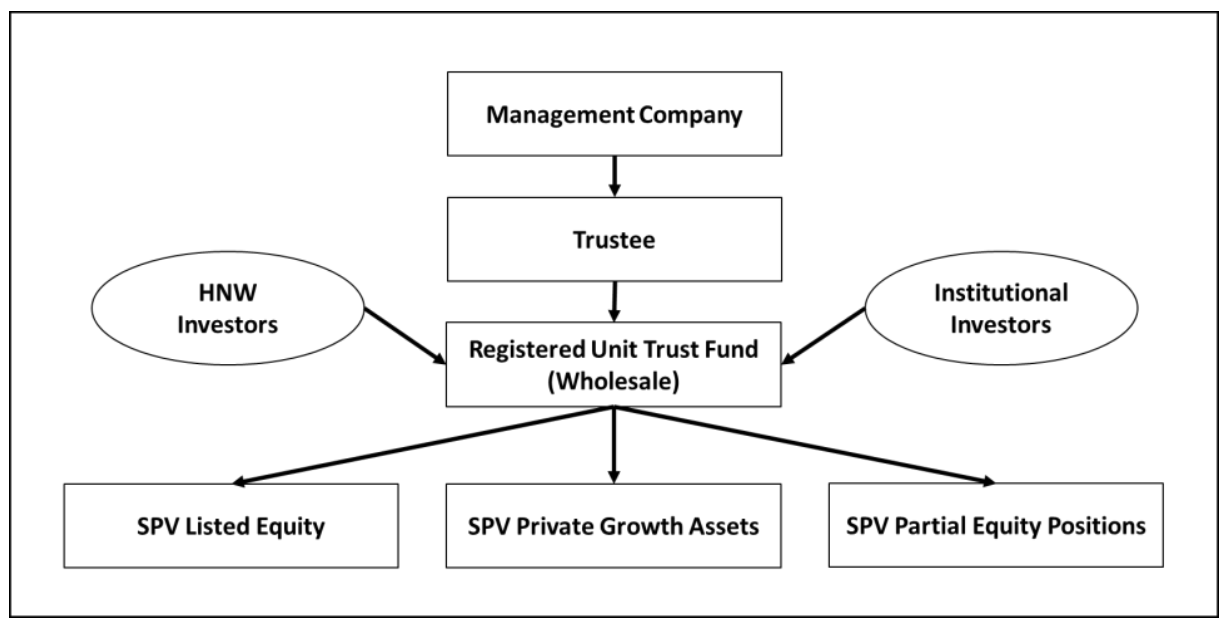

